\title{
Dynamic Distribution of Assembly Tasks in a Collaborative Workcell of Humans and Robots
}

\author{
Dario Antonelli \\ Associate Professor \\ Politecnico di Torino \\ Department of Management and Production \\ Engineering \\ Italy \\ Giulia Bruno \\ Assistant Professor \\ Politecnico di Torino \\ Department of Management and Production \\ Engineering
}

Collaborative robots belong to the enabling technologies of Industry 4.0. They allow the set-up of semi-automatic workcells where robots and humans collaborate in the execution of complex tasks, with unprecedented flexibility if compared with standard robotic cells. This paper addresses some of the many issues that arise from introducing in the factory, not only a new workcell, but also a new working paradigm. The study considers the introduction of collaborative robots in a small production workcell. To increase the chances of success of the new cell, it proposes a method for firstly assigning tasks to human and robotics operators, based on the task characteristics and operator abilities, and then dynamically reassigning tasks to overcome disturbances or delays at the shop floor level. The justification of the method is that outages are frequent in small nonstandardized productions, therefore offline optimized task assignment could be ineffective. The method is tested against an industrial case study and the results are discussed.

Keywords: Human-robot collaboration; man-machine system; industry 4.0; automation; flexible manufacturing system .

\section{INTRODUCTION}

Workcells composed by humans and robots working together in a collaborative way represent an emerging work organization for Small and Medium enterprises (SMEs) working on product assembly [1]. According to a study published by ABI Research, collaborative robotics is expected to increase roughly tenfold between 2015 and 2020, reaching over US\$1 billion from approximately US\$95M in 2015 [2]. Human-Robot Collaboration (HRC) brings benefits to industrial applications in terms of speed, efficiency, better quality of the production and better quality of the workplace[3].

Robots working in a SME pose additional problems with respect to large production. As a matter of fact, small volume assembly is characterized by limited standardization of procedures, frequent variability of product features, lack of tools and brackets to pick and place the parts to be assembled [4]. Full automated robotic cells (for the levels of automation refer to [5]) require the definition of rigorous working procedures that are seldom found in small series assembly.

For small production volumes, some manufacturing operations (e.g., machine loading and unloading, part inspection, part cleaning, bin picking, kitting) are largely done manually [6]. In contrast, a lot of these operations are performed by robots in mass production lines, such as in the automotive industry $[7,8]$. This fact clearly shows a potential for robot introduction for the execution of

Received: November 2018, Accepted: June 2019

Correspondence to: Giulia Bruno, PhD

Politecnico di Torino, Corso Duca degli Abruzzi 24,

10129 Torino, Italy

E-mail: giulia.bruno@polito.it

doi:10.5937/fmet1904723A

(C) Faculty of Mechanical Engineering, Belgrade. All rights reserved several repetitive manufacturing operations.

Setting up purely robotic work cells is not a viable option for most SMEs, because the economic efficiency of robots' use is often undermined by (i) the costs of the implementation of a fully automatic work cell and (ii) the costs and the duration of robot programming for every new task. HRC addresses these issues by relying on human workers for the tasks which are too expensive to automate [9]. Collaboration between human and robot, once solved the safety issues, allows to exploit the dexterity of human and the strength and precision of robot [10].

There are, obviously, some issues that need to be addressed when dealing with the introduction of automation in a factory where most of processes are performed manually. Some issues are related with the necessity of a different task planning strategy and of an effective coordination of the operators. Due to the inherent variability of production factors in a SME, it is advisable that the task assignment be able to change during the work to adapt to varying conditions. Villani et al. point out that, in the design of industrial HumanRobot Collaboration (HRC), the main challenges are the task planning and task allocation that should provide a considerable degree of flexibility [11][41]. Tsarouchi et al., concerning the task planning in HRC, suggest the need for dynamic task allocation and coordination between humans and robots [12]. It means that human operator should provide high-level guidance and the system should be ready to dynamically reschedule operations or re-allocate them to prevent outages. Adaptive scheduling is possible thanks to the availability of real time data about the machine conditions in the factory. Mourtzis and Vlachou present a cloud-based cyberphysical system for adaptive shop-floor scheduling 
using real-time data collection, processing and analysis from the shop floor [13].

The necessity of present study arises from the observation that task allocation methods re-design the process in factories with a pre-existing automation system, whenever the process has high level of standardization. In small batch manual assembly, this is not the case as there are frequently disturbances that would force continuous production stops. Often workers exchange each among the others the tasks to avoid outages using an adaptive strategy. Similarly, in our study, we cycle the task planning by adaptive assignment of tasks followed by real time scheduling.

The paper is oriented to SMEs production managers and helps to overcome the barriers that limit the introduction of HRC in small factories.

The problem to be solved is due to the, usually, poor formalization of the tasks in small series assembly. It is necessary to adopt an easy task representation method, to derive metrics for the task classification, to train a smart classifier using examples from known productions, to tune a decision-making algorithm that should be able to work under high conditions of uncertainty and in real time. The procedure has been tested on a case study taken from manual assembly in a SME. Section 2 describes the state of the art, section 3 the task planning procedure, with special focus on the metrics and the classification algorithm, section 4 the assembly process of a 2-stage snowplow mill and, eventually, section 5 contains a discussion of results and future developments.

\section{RELATED WORKS}

HRC is a research topic since early 1990s. Firstly the focus was on the design of human-compatible robotic hardware [14], then it expanded to human-friendly control modalities [15], social aspects of the interaction [16], natural user interfaces [17], and representation of complex tasks [18-21]. A summary of the progress made up to mid-2000s is done by Goodrich and Schultz [22], which presents a thorough description of different interaction modes, application domains, and the principal open problems in the field. Notwithstanding numerous field applications to mobile, bio-inspired, medical and service robots, HRC research has seen in the past years relatively scarce industrial applications [3].

Due to the introduction of the concept in Industry 4.0 , in the last few years there has been an explosion in the number of industrial applications exploiting HRC [23]. Especially in automotive industry, several authors analyse the adoption of collaborative robotic cells by comparing them with conventional robotic cell [24-26].

The problem of task assignment among workers and robots was studied in some use-cases [27], even if major efforts have been devoted to the safety of human-robot collaboration $[28,29]$.

Considering the production process subdivided in work tasks, it is apparent that some tasks could be performed more proficiently by humans or robots alone, others collaboratively [30-32]. Tan et al. proposed to use a modified version of HTA graphical language, developed for ergonomic studies, to represent, in a hierarchical model, the tasks to be performed [10]. Tsarouchi et al. proposed a decision-making algorithm for task allocation and planning that is based on the evaluation of multiple criteria [33]. The job is divided in several tasks, that are assigned to the human or to the robot following three decision steps (resource suitability, resource availability, minimum operation time) and two evaluation criteria (average resource utilisation and mean flowtime). The approach is particularly effective when HRC is operated in conditions of spatial or temporal separation in the workcell between human and robot.

Recently, key performance indicators have begun to be proposed in literature, to measure the performance of an HRC system, e.g., cycle time, number of completed cycles in a given time period, utilization, efficiency (i.e., the percentage of time that the robot performs productive work while running a program), and waiting time [34]. Dannapfel proposed to design the HRC system in the automotive assembly by optimizing three KPIs, economic efficiency, collaboration efficiency (measured as a percentage of waiting time over cycle time), ergonomics, measured using Ergonomic Assessment Worksheet (EAWS). KPIs allow objective measurement of the efficiency of HRC and its comparison with other types of automation [35]. They are effective at the design stage only if the production is standardized enough to provide reliable values for all the KPIs. Unfortunately, this is not the case of small batch productions.

Our proposal is to combine a first phase in which a static assignment is performed, depending on the characteristics of the tasks and the planned sequence of activities, and a second phase that reassign tasks dynamically, during the work, in case of delays.

The proposed solution is made possible thanks to the emerging of new technologies, founded on Cyber Physical Systems, that allow nowadays the easy reprogramming of collaborative robots, the real time monitoring of robot conditions and the prompt interaction between human and robot. Examples of these technologies have been developed in the research projects FourByThree2 and Symbiotic [36,37].

\section{TASK ALLOCATION}

Differently from manual cells, where tasks are assigned to workers in a balanced way, in HRC workcells humans and robots have different skills that should be exploited as much as possible. Moreover, there is no need to balance the workload between human and robot (the robot can withstand more workload).

The workcell is usually already existing and working in the factory, therefore it is not required to dimension the robot payload or its workspace. Otherwise, as a first step, the robot must be chosen in order to have a payload enough to handle the heaviest parts. The proposed method to task allocation is schematically represented in Fig. 1. It is composed by five main activities. The first activity is to identify the list of tasks involved in the process. Then, for all the tasks, a set of indicators is defined. Indicators were chosen in order to be described by logical or categorical values, easy to input in the industrial field. Based on the indicator 
values of the tasks, a classifier assigns tasks to the following classes: executable only by a human, executable only by a robot, executable indifferently by human or robot, executable mandatorily by both a human and a robot working together. For task assignment it is not important to distinguish if the robot and the human collaborate (share the same space at the same time) or just coexist (share space in different times, or time in different work areas). Then, the task assignment is provided by considering task length and precedence constraints. Once the static assignment is done, the workcell is monitored to control if the plan is respected. In case of tasks with increases or reductions in time, the assignment is dynamically re-performed.

The proposed method can hardly support objective verification. Nevertheless, the verification could be done in two steps: (i) confirmation that the tasks are correctly allocated, i.e., checking that the operator and the robot can execute the tasks assigned to them, and (ii) the comparison of the execution times of both the manual process and the collaborative process to see if the execution time is lower in the second case. Unfortunately to do such verification it is necessary that the new collaborative assembly cell be completely identical to the original one, with just the collaborative robot replacing one human operator. This is not the case of most industrial case studies, where the new cells display extensive renovation of all the equipment such as to make a comparison with the old cell unfair. Each activity is detailed described in the remaining of the section.

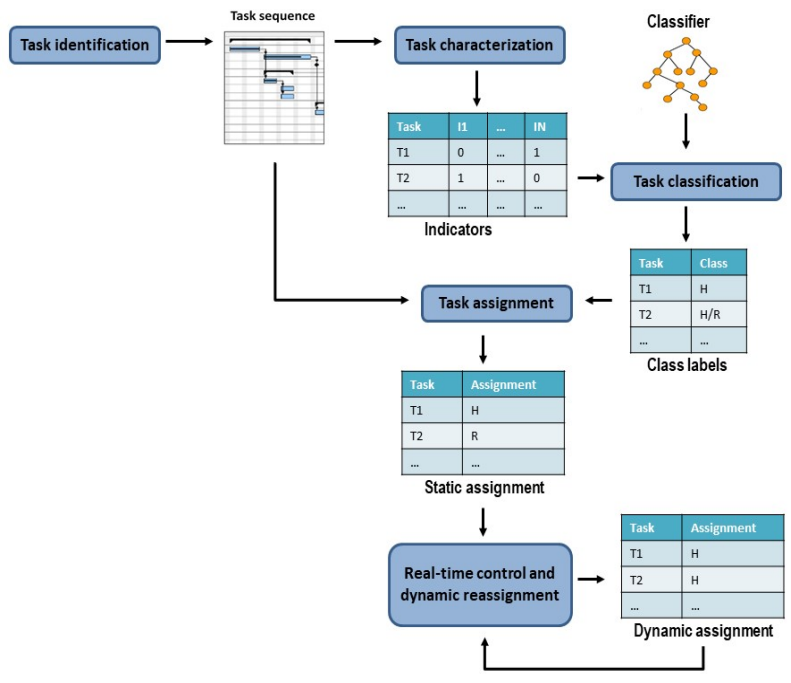

Figure 1. Procedure for task assignment to human and robot

\subsection{Task identification and prioritization}

A collaborative manufacturing process is composed by a set of tasks, identified by the production manager. To each task is assigned a name, a number, a duration, and the precedence with respect to the other tasks, if any. Such parameters are assigned manually before the execution of the process. Table 1 shows an example of four tasks related to a welding process. The first task is the retrieval of tools to execute the operation, the second one a clamp insertion, the third one a welding operation, and the final one the fixing of a support. These tasks have to be executed in sequence.
Table 1. Example of four tasks of a welding process

\begin{tabular}{|c|c|c|c|}
\hline Number & Task & Duration $[\mathrm{s}]$ & Precedence \\
\hline 1 & Tool retrieval & 50 & - \\
\hline 2 & Inserting clamp & 20 & 1 \\
\hline 3 & Welding & 100 & 2 \\
\hline 4 & Fixing support & 80 & 3 \\
\hline
\end{tabular}

\subsection{Task indicators}

Task indicators are used to describe the features of the task, and thus they are decision factors in the selection of the type of collaboration. Several task indicators were proposed by Zanella et al. to characterize automotive manufacturing [38]. We adapted their indicators to small batch assembly: simplified the process time indicators that in unpaced lines are difficult to measure or meaningless, introduced accuracy and dexterity indicators.

The task indicators we considered are the following: weight of the part (W), operator's workzone $(\mathrm{O})$, available room in workzone (R), ergonomics and safety of the process $(\mathrm{E})$, logistic picking $(\mathrm{L})$, product variants (V), dexterity (D), and accuracy (A). The robot safety is not considered in this list because collaborative robots are required to respect safety norms. Most of them are Boolean values. For example, accuracy 0 and dexterity 0 mean that the task has no particular accuracy or dexterity requirements, while accuracy 1 and dexterity 1 mean that the task requires a high accuracy or dexterity. Operator's workzone 0 means that the object is inside the working area, available also to a robot, while 1 means that the object is outside the working area and need to be retrieved. Other values are discrete, such as the weight that can assume three possible values: low, high or exceeding the limit allowed for human operators. Respectively, $0,0.5$ and 1. Table 2 shows an example of application of the indicators to the four welding tasks of Table 1.

The indicators' values for the first task are 0 , meaning that the weight is not a constraint and there aren't particular requirements of dexterity or accuracy. Only 'operator's workzone' is set to 1 because the tools are outside the working area of the robot. The second task is the insertion of a clamp. Due to the weight of the clamp and the fact that the operation requires a high accuracy and dexterity, W, D and A are set to 1

Table 2. Example of four tasks of a welding process

\begin{tabular}{|c|c|c|c|c|c|c|c|c|}
\hline Task & $\mathrm{W}$ & $\mathrm{O}$ & $\mathrm{R}$ & $\mathrm{E}$ & $\mathrm{L}$ & $\mathrm{V}$ & $\mathrm{D}$ & $\mathrm{A}$ \\
\hline Tool retrieval & 0 & 1 & 0 & 0 & 0 & 0 & 0 & 0 \\
\hline Inserting clamp & 1 & 0 & 0 & 0 & 0 & 0 & 1 & 1 \\
\hline Welding & 0 & 0 & 0 & 0 & 0 & 0 & 0 & 1 \\
\hline Fixing support & 0 & 0 & 0 & 0 & 0 & 0 & 0 & 0 \\
\hline
\end{tabular}

\subsection{Task classification}

Classification is the process of identifying to which category an observation belongs, and an algorithm that implements a classification is known as a classifier [39]. Among classifiers, decision trees are a very effective and easy to interpret method, and they are used in several application domains. A decision tree algorithm 
takes as input a set of classified data, and outputs a tree where each end node (leaf) is a decision (a class) and each internal node represents a test. Each leaf represents the decision of belonging to a class of data verifying all tests path from the root to the leaf.

A well-known decision tree algorithm is $\mathrm{C} 4.5$, based on the theory of Shannon entropy [40]. C4.5 classifier is trained by using a set of pre-classified samples. Each sample consists of a vector of the features of the sample and the class in which it falls. At each node of the tree, C4.5 chooses the attribute of the data that most effectively splits its set of samples into subsets enriched in one class or the other. The splitting criterion is the normalized information gain. At the beginning, the attribute with the highest normalized information gain is chosen to make the decision. This attribute is the first node of the tree. The C4.5 algorithm then recurs on the smaller subsets. At each node of the tree, the $\mathrm{C} 4.5$ algorithm chooses one attribute of the data that most effectively splits its set of samples into subsets enriched in one class or the other.

In our case, we considered four classes of tasks: executable by human $(\mathrm{H})$, executable by robot $(\mathrm{R})$, executable by either of the two $(\mathrm{H} / \mathrm{R})$, and executable by the collaborative work of both of them $(\mathrm{H}+\mathrm{R})$. The classifier is trained by using a training set made of previous classified data, like the ones in Tab.3. Particularly, the open source Java implementation of the C4.5 algorithm (J48) in the Weka data mining tool was exploited (http://www.cs.waikato.ac.nz/ml/weka/).

Table 3. Example of classified data used as training set

\begin{tabular}{|c|c|c|c|c|c|c|c|c|c|}
\hline Task & W & O & R & E & L & V & D & A & Class \\
\hline Tool retrieval & 0 & 1 & 0 & 0 & 0 & 0 & 0 & 0 & $\mathrm{H}$ \\
\hline Inserting clamp & 1 & 0 & 0 & 0 & 0 & 0 & 1 & 1 & $\mathrm{H}+\mathrm{R}$ \\
\hline Welding & 0 & 0 & 0 & 0 & 0 & 0 & 0 & 1 & $\mathrm{R}$ \\
\hline Fixing support & 0 & 0 & 0 & 0 & 0 & 0 & 0 & 0 & $\mathrm{H} / \mathrm{R}$ \\
\hline
\end{tabular}

\subsection{Task assignment}

Similarly to Tsarouchi et al. [33], task allocation is achieved through a decision-making algorithm, where the decision steps are the following:

- resource suitability, in order to be ensured that a resource is suitable for the execution of a task;

- resource availability, in order to be identified if a resource is available for the execution of a task;

- operation time, i.e., the time that a resource needs to execute a task. If the two resources have the same minimum operation time, the task can be assigned to either of them.

In case multiple allocations are possible, differently from [33], who adopted as criteria the average resource utilization and the mean flowtime, we considered the robot utilization KPI, thus we maximize the operation time of the robot. The utilization of a robot (r) is computed as the running time of the robot divided by the total required time.

\subsection{Real-time control}

Once the task assignment is completed, the workcell is continuously monitored to control if the plan is respec- ted. However, especially in production characterized by small lot sizes, the time spent in each task can have a high variability, thus the original plan can need a change. Examples of outages that affect specifically collaborative robots are: stops due to unintentional contacts with people, speed loss due to poor robot programming by untrained operator, synchronization faults with the cell supervision system, waiting for the human operator.

Differently from the past, nowadays these outages can be monitored in real time through a Manufacturing Execution System (MES) or through dedicated monitoring software, provided by the main robot manufacturers, like Siemens SIMATIC, Festo CPX-IOT, Robotiq Insights. Usually this software is cloud-based and rely on an edge gateway to allow the integration of machines from different manufacturers.

\section{CASE STUDY}

The selected case study is a manual assembly process of a 2-stage snowplow mill, shown in Fig.2. The assembly is executed in a small factory with small productions that are not suited for full automation, i.e. level 10 in the scale of [5]. The description of the case study was obtained by observing the actual manual process during the assembly of a small number of mills. The process has been recorded on video and all the processing times have been recorded to determine, with the expected high variability of manual processes, mean standard times.

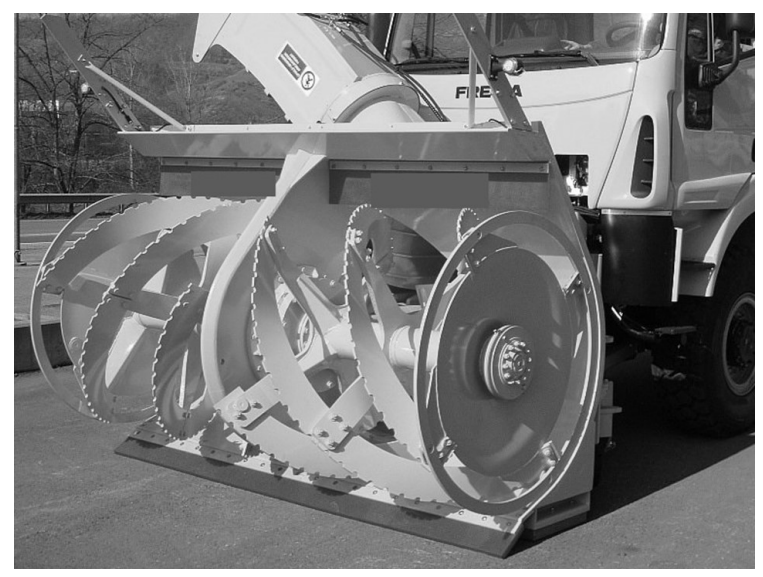

Figure 2. Snowplow mill considered as case study

The process cannot be completely automated, due to the small production volumes. At the same time, it is unsafe and unfit for full manual process: many parts are heavy and must be handed with the help of an overhead travelling crane, arc welding poses additional safety risks due to the shape of the blades. It is apparent the need for a process where a robot will take the risks of welding and will carry most of the weight of parts and human worker will execute the uncountable series of small tasks that require dexterity and flexibility and that are always present in non-automated processes.

\subsection{Task sequence}

The activity diagram of the current process, manually executed, is reported in Figure 3. Each phase is further divided into sub-phases, giving origin to a total of 68 different operations. 


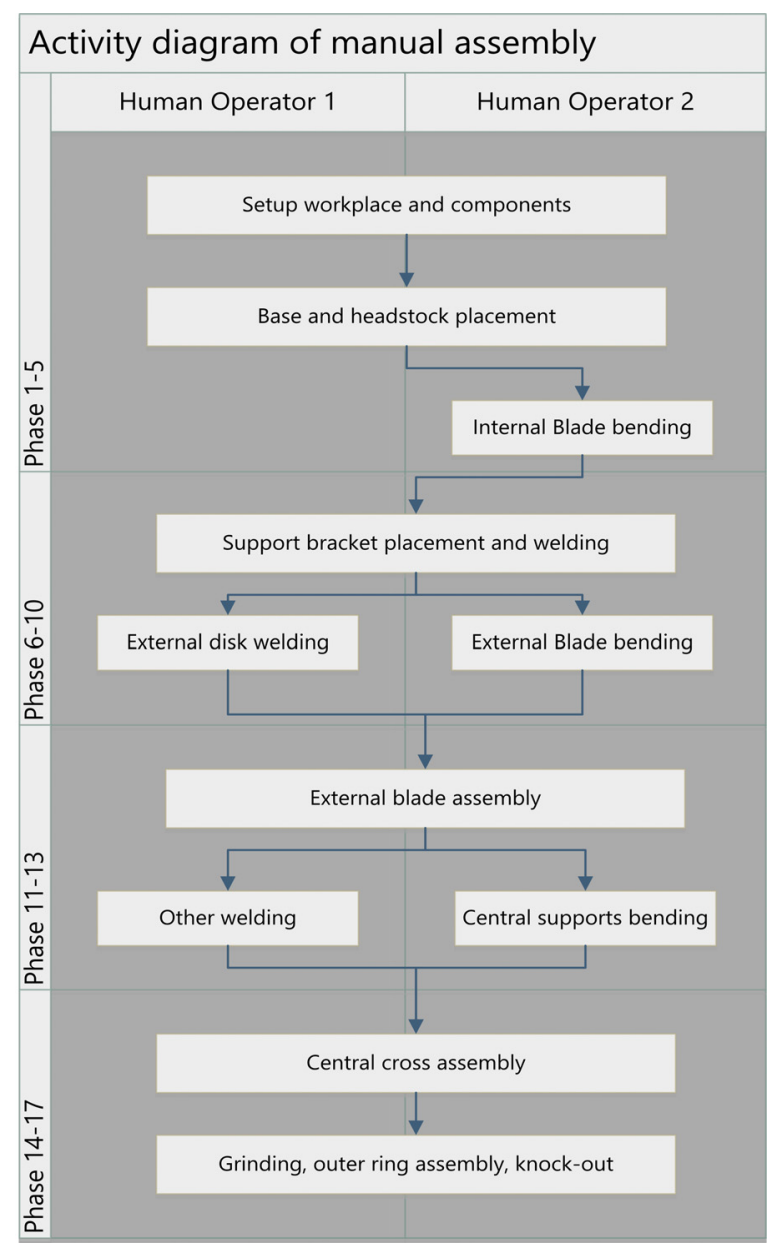

Figure 3. Activity diagram of the snowplow mill manual assembly

The structure is fastened on a slab. The two diagonals are traced to ensure the correct alignment of the radius of the central crossbar, the radius of the inner crossbar and the four-knife brackets. Two reference holes guarantee the placement of the headstock to the slab. There are also other 16 diagonal diagonal holes, needed for fixing the outer disc and the knife mount brackets. The welding in the assembly phase is operated through a gas metal arc welding (GMAW) with $1.2 \mathrm{~mm}$ wire. GMAW is a welding process to melt and join a workpiece by forming an electric arc between a consumable wire electrode and the workpiece metal.

The assembly kit that consists of 4 brackets for fastening the outer disk to the floor and 4 brackets for fixing the knives, 2 lifting rings for the structure repositioning and 2 retaining rings for the crossbar. In the manual process, it is necessary the support of an expensive assembly mask, needless in the robotic process. Assembly is carried out by two operators, both for the need to lift heavy weights and for the joining tasks where one operator prepares the parts to be joined and the other welds.

\subsection{Indicators and classification}

To each of the identified 68 activities has been assigned a value for each indicator, and the corresponding class label. This dataset of 68 classified activities was used to train a C4.5 decision tree, by using the open source Java implementation available on the Weka data mining tool.
To test the model's ability to predict new data that was not used in estimating it, in order not to have problems like overfitting, a cross-validation procedure is often used during the training [41]. It consists in partitioning the known data into two complementary subsets, using only one subset (called training set) to create the model, and the other (called testing set) to validate it. To reduce variability, multiple rounds of crossvalidation are performed using different partitions, and the validation results are combined over the rounds to give an estimate of the model's predictive performance. It's very unlikely that a classifier has a $100 \%$ of accuracy during the training, due to the presence of outliers in the data or to the fact that the training set doesn't contain all the possible combinations of input values.

In order to make our model more effective, we performed a cross-validation on the set of 68 labelled data, by dividing them into four pairs of training and a testing sets. The accuracy achieved by the model is $89.7 \%$. The total number of correctly classified instances is 61 , while the incorrectly classified instances are 7. The resulting classification tree is reported in Fig. 4.

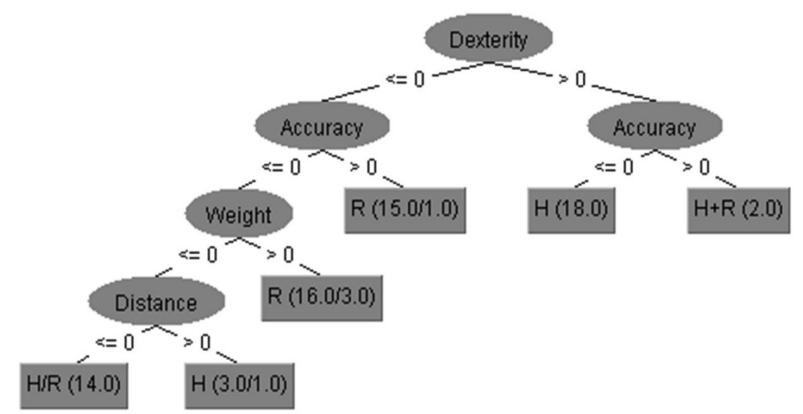

Figure 4. Classification tree

\subsection{Task assignment}

The activity diagram of the revised process, with the support of a collaborative robot, is reported in Fig. 5, while a detailed example of assignment is reported in the upper part of Fig. 6. In this last figure, Task 6.4 can be executed by both a human or a robot, since it is classified as H/R. It is assigned to the robot due to the Utilization measure. In fact, if it was assigned to the human, the utilization of the robot would be $(60 /(60+10+30+30+20)=0.40$. If assigned to the robot, the utilization is $((60+20) /(60+10+30+30+20))=0.53$.

The robot is now in charge of nearly all the welding and of assisting the human when the weight to lift is excessive. The activity diagram shows as human and robots have different and complementary tasks in every process phase. As can be expected, differently from the manual process, now the task assigned to robot and human are often different and separate because it is now necessary to explicitly define the exact timing and functions of robot interventions. On the contrary humans can agree spontaneously and informally how to collaborate and when to avoid overlapping of activities.

\subsection{Dynamic reassignment}

The assignment must be checked dynamically to counteract delays and disturbances that can happen during 
the process. As a matter of fact, in small productions, it frequently happens that times are not respected. In this case, it is advisable that tasks could be reassigned during the work, without the intervention of the production control manager. The performances of the process are measured in real time using the indicators described in [34]. When they reduce below a threshold that must be defined case by case, the reassignment is made. Only the tasks classified as $\mathrm{H}+\mathrm{R}$ can be reassigned.

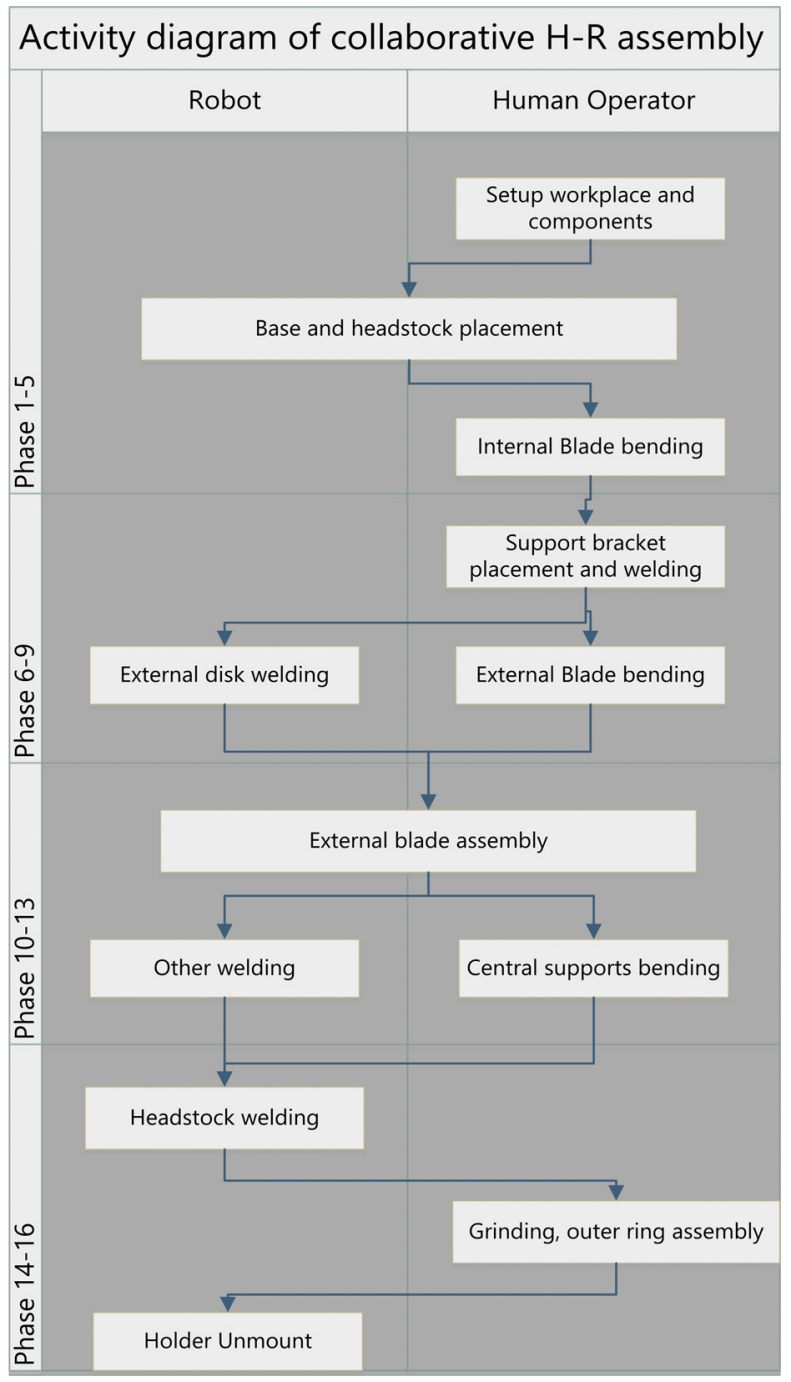

Figure 5. Activity diagram of the collaborative assembly

For example, depending on the current availability of the human and the robot, tasks 5.5-6.4 are assigned as reported in the upper part of Fig. 6, i.e., the robot executes tasks 5.5, while the human executes the tasks 6.1-6.3. If for some reason the human operator needs more time for executing tasks 6.1 and 6.2, then with the dynamic assignment task 6.3 is automatically reassigned to the robot, since the task is classified as $H / R$ and the robot is idle at that time.

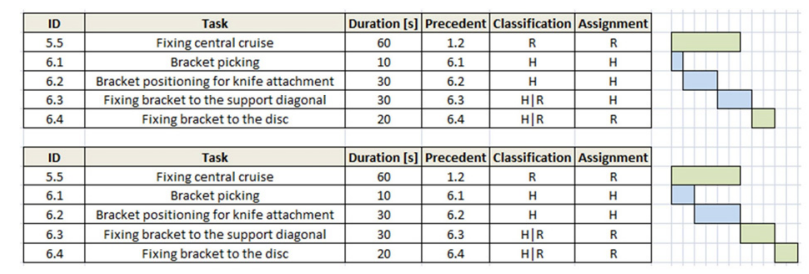

Figure 6. Dynamic reassignment of tasks

\section{CONCLUSIONS}

The paper presents a method for task classification and task assignment between humans and robots in industrial production processes. To implement a real collaborative workcell, it is not enough to buy a collaborative robot and meet the safety requirements, but it is also necessary to redesign the workcell and the methods of organizing the work in the establishment, especially the assignment of tasks.

The proposed procedure for task assignment (i) exploits the different skills of humans and robots to classify tasks, (ii) tries to load the robot instead of the human where possible, and (iii) allows the dynamic reassignment of tasks in case of unexpected delays in task execution.

A case study of the manual assembly of a snowplow mill was investigated. The process can be subdivided in tasks that require the satisfaction of either force or dexterity constraints, therefore fits perfectly the assets of a collaborative workcell. The classifier was trained on a subset of pre-classified tasks and was able to assign the tasks to humans or robots with an accuracy of $89.7 \%$. The results must be considered good because the classification was performed using very few and simple indicators, as they have been obtained in a real factory. The classification errors regard only tasks that could be executed by both human and robot. A dynamic decision-making algorithm modified the assignment proposed by the classifier before the process execution to avoid overlapping of resources. During the process the assignment can be changed again if the system detects a delay in the current operations. This approach is not optimal but allows to avoid frequent outages that are likely to occur in a manual production.

Future works will consider the inclusion of more indicators to better represent task characteristics (including the safety of the task), and the investigation of a communication paradigm to allow an effective exchange of information between humans and robots. Furthermore, more discrete values and fuzzy variables for the indicators, instead of Boolean values, will be considered to make them more realistic. Finally, we will investigate possible verification of our method. It could be done in two steps: (i) the confirmation that the tasks are correctly allocated, i.e., checking that the operator and the robot can execute the tasks allocated to each of them respectively, and (ii) the comparison of the execution times of both the manual process and the collaborative process to see that the execution time is lower in the second case. Unfortunately, such verification can be executed if the new collaborative cell is completely identical to the original one, with just the introduction of a collaborative robot. In most industrial cases, the new cells display extensive renovation of all the equipment such as to make a comparison with the old cells unfair.

\section{REFERENCES}

[1] Grube, D., Malik, A. A., \& Bilberg, A. (2017). Generic challenges and automation solutions in manufacturing SMEs. Annals of DAAAM \& Proceedings, 28. 
[2] Abi Research (2015) Collaborative robotics market exceeds 1 billion dollars by 2020. Retrieved from https:/www.abiresearch.com/press/collaborativerobotics-market-exceeds-us1-billion-/ (20/07/2017)

[3] Helms, E., Schraft, R. D., Hagele, M. (2002). rob@work: Robot assistant in industrial environments. Robot and Human Interactive Communication, 2002. Proceedings. (pp. 399-404). IEEE.

[4] Pieskä, S., Kaarela, J., \& Saukko, O. (2012). Towards easier human-robot interaction to help inexperienced operators in SMEs. In Cognitive Infocommunications (CogInfoCom), 2012 IEEE 3rd International Conference on (pp. 333-338). IEEE.

[5] Parasuraman, R., Sheridan, T. B., \& Wickens, C. D. (2000). A model for types and levels of human interaction with automation. IEEE Transactions on systems, man, and cybernetics-Part A: Systems and Humans, 30(3), 286-297.

[6] Banerjee, A.G., Barnes, A., Kaipa, K.N., Liu, J., Shriyam, S., Shah, N., Gupta, S.K. An Ontology to Enable Optimized Task Partitioning in HumanRobot Collaboration for Warehouse Kitting Operations, Next-Generation Robotics II and Machine Intelligence and Bio-inspired Computation: Theory and Applications IX (2015)

[7] Michalos, G., Makris, S., Papakostas, N., Mourtzis, D., Chryssolouris, G. (2010). Automotive assembly technologies review: challenges and outlook for a flexible and adaptive approach. CIRP Journal of Manufacturing Science and Technology, 2(2), 8191.

[8] Cherubini, A., Passama, R., Crosnier, A., Lasnier, A., Fraisse, P. Collaborative manufacturing with physical human-robot interaction, Robotics and Computer-Integrated Manufacturing, 40, 1-13 (2016)

[9] Antonelli, D., Astanin, S., Bruno, G. (2016) Applicability of human-robot collaboration to small batch production. IFIP Advances in Information and Communication Technology, 480, 24-32.

[10] Tan, J. T. C., Duan, F., Zhang, Y., Arai, T. (2009a) Extending Task Analysis in HTA to Model ManMachine Collaboration in Cell Production, Proceedings of the 2008 IEEE International Conference on Robotics and Biomimetics Bangkok, Thailand

[11] Villani, V., Pini, F., Leali, F., \& Secchi, C. (2018). Survey on human-robot collaboration in industrial settings: Safety, intuitive interfaces and applications. Mechatronics.

[12] Tsarouchi, P., Makris, S., \& Chryssolouris, G. (2016a). Human-robot interaction review and challenges on task planning and programming. International Journal of Computer Integrated Manufacturing, 29(8), 916-931.

[13] Mourtzis, D., \& Vlachou, E. (2018). A cloud-based cyber-physical system for adaptive shop-floor scheduling and condition-based maintenance. Journal of manufacturing systems, 47, 179-198.
[14] Kazerooni H. (1990) Human-robot interaction via the transfer of power and information signals. IEEE Trans On Syst Man Cybern, 20, 450-463.

[15] Luh, J.Y.S., Hu, S. (1998). Comparison of various models of robot and human in human-robot interaction. IEEE Int. Conf. Syst. Man Cybern., 2, 1139-1144.

[16] Breazeal, C., et al. (1998) A motivational system for regulating human-robot interaction. AAAI /IAAI, 54-61.

[17] Kang, S.B., Ikeuchi K. (1995) Toward automatic robot instruction from perception-temporal segmentation of tasks from human hand motion, IEEE Trans On Robot Autom, 11, 670-681.

[18] Yang, J., Xu, Y., Chen, CS. (1997) Human action learning via hidden Markov model, IEEE Trans On Syst Man Cybern, 27, 34-44.

[19] Klingspor, V., Demiris, J., Kaiser, M. (1997) Human robot communication and machine learning, Appl Artif Intell, 11, 719-746.

[20] Lazarević, M. (2005) Optimal Control of Redundant Robots in Human-Like Fashion, FME Transactions (2005) 33, 53-64.

[21] Mandić, P., Lazarević, M. (2013) An Application Example of Webots in Solving Control Tasks of Robotic System, FME Transactions (2013) 41, 153162.

[22] Goodrich, M.A., Schultz, A.C. (2007) Human-robot interaction: a survey, Found Trends Hum-Comput Interact, 1, 203-275.

[23] Almada-Lobo, F. (2016) The Industry 4.0 revolution and the future of manufacturing execution systems (MES), Journal of Innovation Management, 3(4), 16-21.

[24] Morioka, M., Sakakibara, S. (2011) A new cell production assembly system with human robot cooperation, CIRP J. Manuf. Sci. Technol., 59,912

[25] Papakostas, N., Michalos, G., Makris, S., Zouzias, D., Chryssolouris, (2011) Industrial applications with cooperating robots for the flexible assembly, Int. J. Comput. Integr. Manuf., 24(7), 650-660

[26] Stadnicka, D., \& Antonelli, D. (2015). Application of value stream mapping and possibilities of manufacturing processes simulations in automotive. FME Transactions, 43(4), 279-286.

[27] Ding, H., Schipper, M., Bjoern, M. (2014) Optimized task distribution for industrial assembly in mixed humanrobot environments case study on IO module assembly, IEEE International Conference on Automation Science and Engineering

[28]Harper, C., Virk, G. (2010) Towards the development of international safety standards for human robot interaction. Int. J. Social Robotics, 2(3) 229-234

[29] Matthias, B. et al. (2011) Safety of collaborative industrial robots: Certification possibilities for a collaborative assembly robot concept. IEEE ISAM

[30] Antonelli, D., Bruno, G. (2017) Dynamic task sharing strategy for adaptive human-robot collabo- 
rative workcell, 24th International Conference on Production Research

[31] Bruno, G, Antonelli, D. (2018) Dynamic task classification and assignment for the management of human-robot collaborative teams in workcells, International Journal of Advanced Manufacturing Technology, 98 (9-12), pp.2415-2427

[32] Tan, J. T. C., Duan, F., Zhang, Y., Watanabe, K., Kato, R., \& Arai, T. (2009b, October). Humanrobot collaboration in cellular manufacturing: Design and development. In Intelligent Robots and Systems, 2009. IROS 2009. IEEE/RSJ International Conference on (pp. 29-34). IEEE.

[33] Tsarouchi, P., Matthaiakis, A. S., Makris, S., Chryssolouris, G. (2016b). On a human-robot collaboration in an assembly cell. International Journal of Computer Integrated Manufacturing, 30(6), 580589.

[34] Universal Robot (2018) The Top 5 Cobot KPIs: how to measure and improve the performance of collaborative robots (available online from https://blog.robotiq.com/top-five-kpis-for-cobots).

[35] Dannapfel, M., Burggräf, P., Bertram, S., Förstmann, R., Riegauf, A. (2018). Systematic planning approach for heavy-duty human-robot cooperation in automotive flow assembly. International Journal of Electrical and Electronic Engineering and Telecommunications.

[36] Maurtua, I., Ibarguren, A., Kildal, J., Susperregi, L., \& Sierra, B. (2017). Human-robot collaboration in industrial applications: Safety, interaction and trust. International Journal of Advanced Robotic Systems, 14(4).

[37] Wang, X. V., Kemény, Z., Váncza, J., \& Wang, L. (2017). Human-robot collaborative assembly in cyber-physical production: Classification framework and implementation. CIRP annals, 66(1), 5-8.

[38]Zanella, A., Cisi, A., Costantino, M., Di Pardo, M., Pasquettaz, G., Vivo, G. (2017) Criteria Definition for the Identification of HRC Use Cases in Automotive Manufacturing, Procedia Manufacturing.

[39] Tan, P.-N., Steinbach, M., Kumar, V. (2005) Introduction to Data Mining, Pearson.

[40] Quinlan, J. R. (2014) C4.5: programs for machine learning. Elsevier.

[41] Petrović, M., Miljković, Z., \& Babić, B. (2013). Integration of process planning, scheduling, and mobile robot navigation based on TRIZ and multi-agent methodology. FME Transactions, 41(2), 120-129.

\section{ДИНАМИЧКА ДИСТРИБУЦИЈА ЗАДАТАКА МОНТАЖЕ У КОЛАБОРАТИВНОЈ РАДНОЈ ЋЕЛИЈИ ЉУДИ И РОБОТА}

\section{Д. Антонели, Ђ. Бруно}

Колаборативни роботи припадају технологијама које чине индустрију 4.0. Они омогућавају постављање полуаутоматских радних ћелија у којима роботи и људи сарађују у извршавању сложених задатака, уз никад пре достигнуту флексибилност у поређењу са стандардним роботским ћелијама. Овај рад се односи на нека од бројних питања која произилазе из њиховог увођења у фабрику, не само као нове радне ћелије, већ и као нове радне парадигме. Студија разматра увођење колаборативних робота у малу производну радну ћелију. Да би се повећале шансе за успех нове ћелије, предлаже се метода прем којој се прво додељују задаци људима и оператерима робота, на основу карактеристика задатка и способности оператера, а затим се врши динамичка прерасподела задатака како би се превазишли поремећаји или кашњења на нивоу погона. Раллози за методу су да су испади чести у малим нестандардизованим продукцијама, тако да је „оф-лине“ оптимизирано додељивање задатака могло бити неефикасно. Метода је тестирана у односу на индустријску студију случаја и резултати су продискутовани. 